\title{
PENGGUNAAN METODE SMART GAME DAN PEMBELAJARAN KOOPERATIF TIPE MAKE A MATCH UNTUK MENINGKATKAN KEMAMPUAN MENYEBUTKAN NAMA-NAMA DAN TUGAS-TUGAS MALAIKAT ALLAH DI KELAS VII A SMP NU SHOFIYATUL HUDA CIANJUR
}

\author{
Siti Parihah \\ Email : bintudaudz@gmail.com
}

\begin{abstract}
Exciting Learning Will Occur If The Teacher Is Creative In developing the learning method. Students' difficulties in understanding the material can occur because of a teacher's method that tends not to bring learning to a pleasant atmosphere. Therefore, the formulation of the problem in this research is how the use of smart game method and cooperative learning can improve students' understanding in PAI material. The purpose of this study is that we can know how the use of a creative method can make learning fun and even able to improve students' understanding of absorbing the material. The data collection technique is done by observation, daily journal, and evaluation. This research was conducted in class VII A SMP NU Shofiatul Huda Cianjur on basic competence mention the names and duties of angel Allah by using method of smart game and cooperative learning type make a match. The conclusion of the result is the use of this method is able to improve students' ability in mentioning the names and tasks of angels and students are very happy to learn with smart game method like this.
\end{abstract}

Keywords:

Smart Game Method, Cooperative Learning type Make a Match, PAI material (angel name and task)

\begin{abstract}
Abstrak :Pembelajaran yang menyenangkan akan terjadi jika guru kreatif dalam mengembangkan metode pembelajaran. Kesulitan siswa dalam memahami materi dapat terjadi karena metode guru yang cenderung tidak membawa pembelajaran pada suasana yang menyenangkan. Karena itu, yang menjadi rumusan masalah dalam penelitian ini adalah bagaimana penggunaan metode smart game dan pembelajaran kooperatif mampu meningkatkan pemahaman siswa dalam materi PAI. Adapun tujuan penelitian ini adalah agar kita dapat mengetahui bagaimana penggunaan suatu metode yang kreatif dapat membuat pembelajaran menjadi menyenangkan bahkan mampu meningkatkan pemahaman siswa dalam menyerap materi. Adapun teknik pengumpulan data yang dilakukan adalah dengan observasi, jurnal harian, dan melakukan evaluasi. Penelitian ini dilaksanakan di kelas VII A SMP NU Shofiatul Huda Cianjur pada kompetensi dasar menyebutkan nama-nama dan tugas-tugas malaikat Allah dengan menggunakan metode smart game dan pembelajaran kooperatif tipe make a match. Kesimpulan hasilnya adalah penggunaan metode ini mampu meningkatkan kemampuan siswa dalam menyebutkan nama dan tugas malaikat serta siswa sangat senang belajar dengan metode smart game seperti ini.
\end{abstract}

Kata Kunci

Metode Smart Game, Pembelajaran Kooperatif tipe Make a Match, materi PAI (nama dan tugas malaikat)

\section{PENDAHULUAN}

Pendidikan agama adalah pendidikan yang memberikan pengetahuan dan membentuk sikap, kepribadian dan keterampilan peserta didik dalam mengamalkan ajaran agamanya, yang dilaksanakan sekurang-kurangnya melalui mata pelajaran / kuliah pada semua jalur, jenjang dan jenis pendidikan (pasal 1 ayat (1) Peraturan 
Pemerintah nomor 55 Tahun 2007 tentang Pendidikan Agama dan Pendidikan Keagamaan). Dalam pasal 5 ayat (7) disebutkan bahwa pendidikan agama diselenggarakan secara interaktif, inspiratif, menyenangkan, menantang, mendorong kreativitas dan kemandirian, serta menumbuhkan motivasi untuk hidup sukses.

Lebih lanjut, dalam lampiran Peraturan Menteri Pendidikan Nasional Republik Indonesia Nomor 41 Tahun 2007 tentang Standar Proses Untuk Satuan Pendidikan Dasar dan Menengah dijelaskan bahwa dalam pelaksanaan kegiatan inti, pelaksanaan pembelajaran dilakukan secara interaktif, inspiratif, menyenangkan, menantang, memotivasi peserta didik untuk berpartisipasi aktif, serta memberikan ruang yang cukup bagi prakarsa, kreativitas, dan kemandirian sesuai dengan bakat, minat dan perkembangan fisik serta psikologis peserta didik. Kegiatan inti menggunakan metode yang sesuai dengan karakteristik peserta didik dan mata pelajaran yang dapat meliputi proses eksplorasi, elaborasi dan konfirmasi.

Dalam kegiatan eksplorasi, guru, antara lain, memfasilitasi terjadinya interaksi antar peserta didik serta antara peserta didik dengan guru, lingkungan dan sumber belajar lainnya; dan melibatkan peserta didik secara aktif dalam setiap kegiatan pembelajaran.

Dalam kegiatan elaborasi, guru, antara lain, memfasilitasi peserta didik dalam pembelajaran kooperatif dan kolaboratif; memfasilitasi peserta didik berkompetisi secara sehat untuk meningkatkan prestasi belajar; dan memfasilitasi peserta didik untuk menyajikan hasil kerja individual maupun kelompok.

Sedangkan dalam kegiatan konfirmasi, guru, antara lain, memberikan umpan balik positif dan penguatan dalam bentuk lisan, tulisan, isyarat, maupun hadiah terhadap keberhasilan peserta didik.

Pada umumnya, siswa mengalami kesulitan dalam menguasai kompetensi dasar tentang beriman kepada malaikat Allah. Hal ini nampak pada belum maksimalnya kemampuan dalam menyebutkan nama-nama dan tugas-tugas malaikat Allah. Di sisi lain, pembelajaran yang berpusat pada guru, suasana kelas yang kaku, media pembelajaran yang kurang mendukung, pengorganisasian siswa yang belum optimal dan penggunaan mono methode merupakan faktor-faktor penyebab rendahnya hasil belajar siswa.

Berdasarkan uraian tersebut, maka permasalahan yang dihadapi guru PAI adalah bagaimana menciptakan model-model pembelajaran yang variatif, menyenangkan, dan bermakna sehingga siswa dapat mandiri dan mencapai ketuntasan dalam belajar. Permasalahan inilah yang mendorong penulis untuk memodifikasi berbagai model dan teknik pembelajaran sesuai dengan karakteristik materi, karakteristik siswa dan disesuaikan dengan kemampuan guru.

Berdasarkan latar belakang masalah yang dikemukakan, maka yang dijadikan rumusan masalah penelitian ini adalah "Bagaimana penggunaan metode smart game dan pembelajaran kooperatif tipe make a match dalam meningkatkan kemampuan menyebutkan nama-nama dan tugas-tugas malaikat Allah?" 
Penelitian ini bertujuan agar kita dapat mengetahui bagaimana penggunaan metode smart game dan pembelajaran kooperatif tipe make a match dalam meningkatkan kemampuan menyebutkan nama-nama dan tugas-tugas malaikat Allah.

\section{Pembelajaran PAI}

Adapun dasar teoritis yang digunakan dalam penelitian ini adalah teori tentang pembelajaran PAI, pola metode smart game, dan cooperative learning type make a match. pertama pembelajaran PAI, berikut di bawah ini adalah simpulan yang diambil oleh Zakiah Daradjat mengenai definisi Pendidikan Agama Islam (Darajat, 2006, p. 86)

a) Pendidikan agama Islam ialah usaha berupa bimbingan dan asuhan terhadap anak didik agar kelak setelah selesai pendidikannya dapat memahami dan mengamalkan ajaran agama Islam serta menjadikannya sebagai pandangan hidup (way of life).

b) Pendidikan agama Islam ialah pendidikan yang dilaksanakan berdasar ajaran Islam.

c) Pendidikan agama Islam adalah pendidikan dengan melalui ajaran-ajaran agama Islam, yaitu berupa bimbingan dan asuhan terhadap anak didik agar nantinya setelah selesai dari pendidikan ia dapat memahami, menghayati, dan mengamalkan ajaran-ajaran agama Islam yang telah diyakininya secara menyeluruh, serta menjadikan ajaran agama Islam itu sebagai suatu pandangan hidupnya demi keselamatan dan kesejahteraan hidup di dunia maupun di akhirat kelak.

Dari pandangan para ahli di atas, dapat disimpulkan bahwa pendidikan agama Islam adalah usaha sadar berupa pembinaan, pengasuhan, pemberian ilmu pengetahuan, dan keterampilan dalam hal ajaran Islam yang dilakukan oleh perorangan atau lebih kepada peserta didik, agar ia bertakwa kepada Allah dan dapat menjalankan atau mengamalkan seluruh ajaran Islam dengan baik serta maksimal, sehingga agama Islam dijadikannya sebagai pandangan hidup.

Menurut Muhammad Alim tujuan pendidikan agama Islam adalah membantu terbinanya para siswa muslim yang beriman, berilmu, dan beramal sesuai dengan ajaran Islam. Hal demikian didasarkan pada hakikat pembangunan nasional adalah pembangunan manusia Indonesia seutuhnya, yang selanjutnya dijabarkan dalam UU No. 2 tahun 1989. Pada pasal 2 dijelaskan bahwa pendidikan nasional adalah untuk membentuk manusia Indonesia seutuhnya, yaitu manusia yang beriman dan bertaqwa kepada Tuhan Yang Maha Esa, berbudi pekerti luhur, cerdas dan terampil, sehat jasmani dan rohani, memiliki rasa tanggung jawab kemasyarakatan dan kebangsaan (Alim, 2011, p. 7).

Sedangkan menurut Ramayulis, ada empat aspek tujuan pendidikan Islam, yaitu (Ramayulis, 2002, pp. 222-225) : 


\section{- Tujuan Jasmaniah ( ahdaf al-jismiah)}

Tujuan pendidikan harus dikaitkan dengan tugas manusia selaku khalifah Allah di muka bumi ini yang harus memiliki kemampuan jasmani yang bagus disamping rohani yang teguh. Rasul bersabda yang artinya " orang mukmin yang kuat, lebih baik dari mukmin yang lemah". Kuat di sana adalah kuat jasmaniah. Jadi tujuan pendidikan Islam adalah untuk membentuk manusia muslim yang sehat jasmaniah serta memiliki keterampilan yang tinggi.

\section{- Tujuan Rohaniah (Ahdaf al-Ruhhiyah)}

Tujuan ruhaniah diarahkan kepada pembentukan akhlak mulia, yang mana oleh ahli pendidikan barat dikategorikan sebagai tujuan pendidikan religius, yang kebanyakan pemikir Islam tidak menyetujui istilah itu karena akan memberikan kesan akan adanya tujuan pendidikan yang non religius dalam Islam. Pendidikan Islam bertujuan untuk membimbing manusia sedemikian rupa hingga ia selalu tetap berada didalam hubungan denganNya.

\section{- Tujuan Akal ( Ahdaf al-Aqliyah)}

Tujuan ini bertumpu pada pengembangan intelegensia (kecerdasan) yang berada dalam otak. Sehingga mampu memahami dan menganalisis setiap fenomena -fenomena ciptaan Allah. Kemudian dengan panca indra manusia di didik untuk mengobservasi menggunakan akal kecerdasannya, yang akan menjadikan tambahan khazanah pengetahuan yang di kembangkan menjadi ilmu-ilmu pengetahuan. Proses intelektualisasi pendidikan Islam terhadap sasaran pendidikannya bebeda dengan proses yang sama yang dilakukan pendidikan non islami. Ciri khas pendidikan Islam adalah selalu menginternalisasi dan mentransformasikan nilai-nilai Islami seperti keimanan, akhlak, dan ubudiah serta muamalah ke dalam pribadi manusia.

\section{- Tujuan Sosial ( ahdaf al-ijtimaiah)}

Tujuan social ini merupakan pembentukan kepribadian yang utuh. Dimana identitas individu tersebut tercermin sebagai manusia yang hidup pada masyarakat yang plural (majemuk). Tujuan ini penting karena manusia terlahir sebgai khalifah Tuhan di bumi seyogianya mempunyai kepribadian yang utama dan seimbang. Yang karenanya tidak mungkin manusia menjauhkan diri dari bermasyarakat.

\section{Prosedur Pembelajaran PAI \\ Perencanaan Pembelajaran}

Perencanaan merupakan suatu hal yang sangat penting dalam mengerjakan sesuatu untuk memperoleh hasil yang memuaskan sesuai dengan harapan. Dalam hal apapun pasti terdapat tujuan dan target yang ingin dicapai. Sebelum proses memperoleh tujuan itu dilaksanakan, alangkah lebih baiknya proses tersebut di rencanakan terlebih dahulu agar semua proses terkonsep dengan baik dan rapi sehingga akan menghasilkan output yang memuaskan sesuai dengan target dan tujuan. Dalam ilmu ekonomipun kita sering mendengar urutan seperti planning, organizing, actuating, controling. Urutan 
pertama yang di letakan oleh para ahli ekonomipun adalah planning yang artinya perencanaan baru menginjak ke hal yang selanjutnya. Ini di karenakan sebuah perencanaan itu sangat diperlukan untuk terlaksananya proses secara baik dan rapi.

Begitupun dalam hal pendidikan, khususnya dalam pembelajaran di dalam kelas atau proses belajar mengajar di dalam kelas, dimana seorang guru tidak sembarangan mengajar peserta didiknya, tetapi ada aturan atau pedoman yang harus dilaksanakan agar tujuan pendidikan tersebut dapat tercapai. Sebelum melaksanakan kegiatan pembelajaran, seorang guru harus terlebih dahulu membuat perencanaan pembelajaran. Apa sebenarnya definisi perencanaan pembelajaran itu?

Penulis akan memulai dari definisi perencanaan terlebih dahulu. Perencanaan merupakan gabungan dari pe-rencana-an yang memiliki kata dasar "rencana". Dalam Kamus Bahasa Indonesia, rencana adalah rancangan terhadap sesuatu yang akan dilakukan (Santoso, -, p. 346).

Sedangkan menurut asumsi Terry menyatakan bahwa perencanaan adalah menetapkan pekerjaan yang harus dilaksanakan oleh kelompok untuk mencapai tujuan yang digariskan. Perencanaan mencakup kegiatan pengambilan keputusan. Sedangkan menurut Banghart dan Trull mengemukakan bahwa perencanaan adalah awal dari semua proses yang rasional dan mengandung sifat optimisme yang didasarkan atas kepercayaan bahwa akan dapat mengatasi berbagai macam permasalahan. Nana Sudjana mengatakan bahwa perencanaan adalah proses yang sistematis dalam pengambilan keputusan tentang tindakan yang akan dilakukan pada waktu yang akan datang (Majid, 2012, p. 16).

Terlihat jelas bahwa pembelajaran adalah sebuah proses yang dilakukan oleh pendidik agar peserta didik dapat aktif dalam belajar sehingga ia mampu mengeluarkan potensi yang ada di dalam dirinya. Bedanya dengan proses pengajaran dulu adalah hanya guru yang mentransfer pengetahuan saja kepada siswanya tetapi pembelajaran menuntut siswanya untuk aktif agar ia tidak hanya mampu mendengarkan guru tanpa berkomentar apapun tetapi juga ikut berbicara mengeluarkan pendapat-pendapatnya. Dari kedua definisi tersebut, kita dapat menggabungkan secara utuh definisi dari perencanaan pembelajaran.

Dari penjelasan diatas, dapat kita lihat bahwa karakteristik perencanaan pembelajaran yang pertama adalah perencanaan pembelajaran merupakan hasil dari proses berpikir. Kedua, perencanaan pembelajaran disusun untuk mengubah perilaku siswa sesuai dengan tujuan yang ingin dicapai. Ketiga, perencanaan pembelajaran berisi tentang rangkaian kegiatan yang harus dilaksanakan untuk mencapai tujuan. Dengan demikian penulis menyimpulkan bahwa perencanaan pembelajaran adalah suatu rancangan tertulis tentang rangkaian kegiatan yang akan dilaksanakan dalam proses pembelajaran dan dijadikan sebagai acuan atau pedoman untuk mencapai tujuan. 


\section{Silabus}

Selain RPP, ada juga perangkat lain yang harus disiapkan oleh seorang guru untuk kelancaran proses pembelajaran PAI, yaitu silabus. Berikut beberapa pendapat mengenai pengertian dari silabus (Majid, 2012, p. 38) :

Silabus adalah ancangan pembelajaran yang berisi rencana bahan ajar mata pelajaran tertentu pada jenjang dan kelas tertentu, sebagai hasil dari seleksi, pengelompokan, pengurutan, dan penyajian materi kurikulum, yang dipertimbangkan berdasarkan ciri dan kebutuhan daerah setempat.

Sedangkan menurut Yulaelawati dalam Abdul Majid, menjelaskan bahwa silabus merupakan seperangkat rencana serta pengaturan pelaksanaan pembelajaran dan penilaian yang disusun secara sistematis memuat komponen-komponen yang saling berkaitan untuk mencapai penguasaan kompetensi dasar (Majid, Perencanaan Pembelajaran, 2012, hal. 39). Sehingga dapat disimpulkan bahwa silabus adalah salah satu perangkat perencanaa pembelajaran yang harus disiapkan oleh guru sebelum melakukan pembelajaran, yang isinya meliputi : standar kompetensi, kompetensi dasar, indikator, materi pokok, pengalaman belajar, alokasi waktu, sumber/bahan/alat dan penilaian. Bedanya dengan RPP adalah silabus dibuat untuk satu semester dengan isi yang masih global. Sedangkan RPP biasanya dibuat untuk satu kali pertemuan atau beberapa pertemuan, dan isinya memuat rincian yang ada di dalam sebuah silabus yang dicantumkan kembali ke dalam RPP sampai lebih rinci hingga ke teknis pelaksanaan pembelajarannya.

\section{Pelaksanaan Pembelajaran}

Kegiatan pembelajaran diarahkan untuk memberdayakan semua potensi siswa untuk menguasai kompetensi yang diharapkan. Kegiatan pembelajaran mengembangkan kemampuan untuk mengetahui, memahami, melakukan sesuatu, hidup dalam kebersamaan dan mengaktualisasikan diri. Dengan demikian, kegiatan pembelajaran perlu (Majid, Belajar dan Pembelajaran PAI, 2012, p. 24) :

1) Berpusat pada siswa

2) Mengembangkan kreativitas siswa

3) Menciptakan kondisi yang menyenangkan dan menantang

4) Bermuatan nilai, etika, estetika, logika, dan kinestetika, dan

5) Menyediakan pengalaman belajar yang beragam.

Dalam kerangka itu, pengembangan program dilakukan berdasarkan pendekatan kompetensi. Penggunaan pendekatan ini memungkinkan desain program dapat dilaksanakan secara efektif, efisien, dan tepat. Hasil-hasil pembelajaran dinilai dan dijadikan umpan balik untuk mengadakan perubahan terhadap tujuan pembelajaran dan prosedur pembelajaran yang dilaksanakan sebelumnya. Menurut Stanley Elam dalam Oemar Hamalik yang dikutip kembali oleh Abdul Majid (2012 : 25), menjelaskan bahwa langkah-langkah pengembangan pembelajaran dapat dilakukan sebagai berikut :

1) Spesifikasi asumsi-asumsi atau preposisi-preposisi yang mendasar 
2) Mengidentifikasi kompetensi

3) Menggambarkan secara spesifik kompetensi-kompetensi

4) Menentukan tingkat-tingkat kriteria dan jenis assessment

5) Pengelompokan dan penyusunan tujuan pengajaran

6) Desain strategi pembelajaran

7) Mengorganisasikan sistem pengelolaan

8) Melaksanakan percobaan program

9) Menilai desain pembelajaran

10) Memperbaiki program.

Langkah-langkah pengembangan pembelajaran tersebut dapat dilihat pada bagan di bawah ini (Majid, Perencanaan Pembelajaran, 2012, p. 33) :

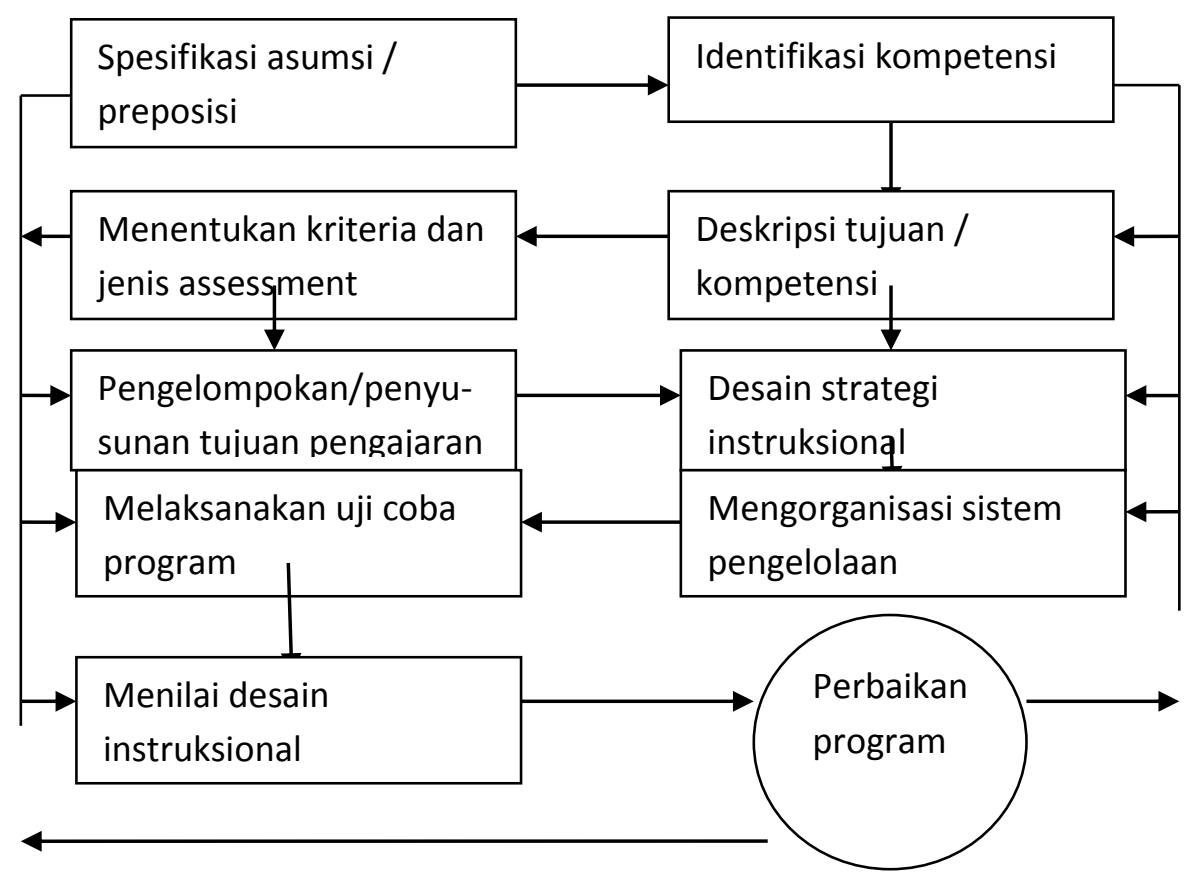

Langkah-langkah pengembangan pembelajaran

Bagan di atas menunjukan bahwa pelaksanaan pembelajaran dapat dikembangkan sesuai dengan kekreativitasan guru itu sendiri. Pelaksanaan pembelajaran merupakan aplikasi dari perencanaan pembelajaran yang telah dibahas sebelumnya. Pada pelaksanaan ini guru mulai menerapkan berbagai model, metode, bahkan teknik pembelajaran sesuai dengan konsep yang telah direncanakan. Guru hanya perlu melaksanakan apa yang ada di dalam RPP sesuai dengan langkah-langkah pembelajarannya. Aplikasi model, metode, dan teknik yang telah dipersiapkan sebelumnya haruslah dilaksanakan sesuai dengan perencanaannya, meskipun terkadang memang ada perubahan, namun guru harus menjadikan hal tersebut sebagai evaluasi dari pelaksanaan pembelajaran tersebut. 


\section{Metode Smart Game}

Selanjutnya metode smart game, bermain adalah segala kegiatan yang dapat menimbulkan kesenangan bagi anak yang dilakukan dengan sukarela tanpa paksaan dan tekanan dari luar. (Hibana. S. Rahman) Metode bermain adalah cara atau pendekatan dengan bermain dalam belajar untuk mencapai tujuan yang diharapkan. Permainan bisa dijadikan sebagai salah satu strategi pembelajaran, karena permainan memegang peranan penting bagi perkembangan anak. Montessori, seorang tokoh pendidikan menekankan bahwa ketika anak bermain, ia akan mempelajari dan menyerap segala sesuatu yang terjadi di lingkungan sekitarnya. Jean Piaget menyatakan bahwa terdapat beberapa tahapan intelektual anak yaitu:

a) Usia $0-2$ tahun disebut tahap / masa sensorimotor

b) Usia $2-7$ tahun adalah masa pra-operasional

c) Usia 7 - 11 tahun disebut konkrit operasional

d) Usia 11 - 14 tahun adalah masa formal operasional.

Bermain adalah kegiatan yang dilakukan semata-mata untuk menimbulkan kesenangan. Hal ini senada dengan pendapat Piaget yang menjelaskan bahwa bermain terdiri atas tanggapan yang diulang semata untuk kesenangan fungsional. Pengertian ini membedakan antara bermain dengan bekerja, yang memiliki tujuan tertentu dan tidak harus menimbulkan kesenangan. Elizabeth B. Hurlock seorang pakar perkembangan anak mengungkapkan bahwa bermain memberi manfaat yang besar bagi perkembangan anak (Hamhor). Karena itu metode belajar melalui permainan ini dijadikan salah satu alternatif untuk dapat menstimulasi perkembangan kecerdasan anak dalam belajar.

Metode permainan adalah merupakan metode pembelajaran dimana materi disampaikan melalui suatu kegiatan yang menyenangkan (menggembirakan) yang dapat menunjang terciptanya tujuan instruksional dalam pengajaran PAI baik aspek kognitif, afektif, maupun psikomotorik. Permainan sebagai bagian dari proses belajar dan dirancang menjadi suatu aksi/kejadian yang dialami sendiri oleh siswa kemudian dalam proses refleksi, disimpulkan untuk mendapat hikmah yang mendalam. Inilah yang dimaksud dengan metode smart game. Smart berarti cerdas dan game berarti permainan. Smart game adalah permainan yang dirancang sedemikian rupa untuk meningkatkan kecerdasan anak didik (repository.umy.ac.id).

Dalam penelitian ini, permainan yang digunakan adalah permainan tepuk malaikat. Langkah-langkahnya sebagai berikut : Guru membagikan hand out "tepuk malaikat", Siswa melakukan permainan tepuk malaikat dengan bimbingan guru, Guru membagi siswa ke dalam beberapa kelompok, Siswa melakukan permainan tepuk malaikat antar kelompok dengan model tanya jawab, Siswa melakukan permainan tepuk malaikat bersama teman sebangku dengan model tanya jawab., Refleksi dan kesimpulan.

\section{Pembelajaran Kooperatif Tipe Make A Match}


Teori dasar yang terakhir adalah tentang pembelajaran kooperatif tipe make a match. Eggen dan Kauchak (1993: 319) mendefinisikan pembelajaran kooperatif sebagai sekumpulan strategi mengajar yang digunakan guru agar siswa saling membantu dalam mempelajari sesuatu. Oleh karena itu belajar kooperatif ini juga dinamakan "belajar teman sebaya." Menurut Slavin (1997), pembelajaran kooperatif, merupakan metode pembelajaran dengan siswa bekerja dalam kelompok yang memiliki kemampuan heterogen (Holil).

Model pembelajaran kooperatif adalah model pembelajaran dengan setting kelompok-kelompok kecil dengan memperhatikan keberagaman anggota kelompok sebagai wadah siswa bekerjasama dan memecahkan suatu masalah melalui interaksi sosial dengan teman sebayanya, memberikan kesempatan pada peserta didik untuk mempelajari sesuatu dengan baik pada waktu yang bersamaan dan ia menjadi narasumber bagi teman yang lain. Jadi Pembelajaran kooperatif merupakan model pembelajaran yang mengutamakan kerjasama diantara siswa untuk mencapai tujuan pembelajaran (Ipotes).

Johnson \& Johnson (1992) menyebutkan adanya lima ciri pokok pembelajaran kooperatif yaitu: 1) adanya saling ketergantungan positif, 2) adanya interaksi tatap muka, 3) adanya akuntabilitas individual, 4) adanya ketrampilan menjalin hubungan antar pribadi, 5) adanya evaluasi proses kelompok. Dalam praktek pengajaran di kelas, metode kooperatif terdiri dari beberapa teknik. Dalam penelitian ini istilah kooperatif dimaksudkan sebagai suatu metode yang mengandung unsur-unsur kerjasama, saling berbagi, dan sikap empati antar anggota kelompok (Rahmat Aziz, 2008).

Salah satu model pembelajaran kooperatif adalah tipe Make a Match yang dikembangkan oleh Lorna Curran pada tahun 1994. Salah satu keunggulan model ini menurut Rusman, (2014) adalah "Siswa mencari pasangan sambil belajar mengenai suatu konsep atau topik dalam suasana yang menyenangkan". Teknik ini biasa digunakan dalam semua mata pelajaran dan untuk semua tingkatan (Rijal, 2017).

Model pembelajaran kooperatif tipe Make a Match bertujuan untuk memperluas wawasan serta kecermatan siswa dalam menyelami suatu konsep. Sebelum permainan dimulai, guru menyampaikan tujuan pembelajaran, motivasi belajar, pokok bahasan, mengorganisasikan siswa, menyampaikan langkah-langkah permainan, membimbing siswa, dan mengevaluasi hasil serta memberikan penghargaan. Rusman (2014) menuliskan penggunaan model pembelajaran Kooperatif Tipe Make a Match mengikuti langkah-langkah sebagai berikut:

1. Guru menyiapkan beberapa kartu yang berisi beberapa konsep atau topik yang mungkin cocok untuk sesi review (satu sisi kartu berupa kartu soal dan sisi sebaliknya berupa kartu jawaban).

2. Setiap siswa mendapat satu buah kartu dan memikirkan jawaban atau soal dari kartu yang dipegang. 
3. Siswa mencari pasangan yang mempunyai kartu yang cocok dengan kartunya (kartu soal/kartu jawabanSiswa yang dapat mencocokkan kartunya sebelum batas waktu diberi poin.

4. Setelah satu babak kartu dikocok lagi agar tiap siswa mendapat kartu yang berbeda dari sebelumnya, demikian seterusnya.

5. Proses terakhir model pembelajaran ini adalah dengan membuat klarifikasi dan kesimpulan (Rijal, 2017).

\section{METODOLOGI PENELITIAN}

Metode pengumpulan data dalam penelitian ini yaitu catatan observasi, jurnal harian dan hasil evaluasi yang dilakukan sejak awal penelitian (pre test) sampai siklus terakhir bersama mitra kolaborasi.

Catatan observasi dipergunakan untuk mengetahui aktifitas guru dalam pembelajaran, peningkatan partisipasi siswa dalam pembelajaran dan manajemen kelas. Jurnal harian dilakukan untuk mengetahui respon siswa terhadap pembelajaran dengan metode smart game dan pembelajaran kooperatif tipe make a match. Sedangkan evaluasi dilakukan untuk mengukur peningkatan penguasaan siswa terhadap materi pembelajaran PAI.

Adapun teknik analisis data yang digunakan adalah model alur, yaitu reduksi data, penyajian data dan penarikan kesimpulan (Aqib, 2007, p. 106).

\section{HASIL PENELITIAN DAN PEMBAHASAN}

Penelitian Tindakan Kelas (PTK) ini, pelaksanaannya mengikuti alur sebagai berikut: Perencanaan, meliputi penetapan materi pembelajaran Pendidikan Agama Islam dan penetapan alokasi waktu pelaksanaannya (Pebruari s.d. April 2017), Pelaksanaan (Tindakan) meliputi seluruh proses kegiatan belajar mengajar menggunakan metode smart game dan pembelajaran kooperatif tipe make a match. Observasi, dilaksanakan bersamaan dengan proses pembelajaran, meliputi aktifitas guru dalam pembelajaran dan peningkatan partisipasi siswa dalam pembelajaran. Refleksi, meliputi kegiatan analisis hasil pembelajaran dan menyusun rencana perbaikan pada siklus berikutnya.

Pelaksanaan penelitian dilakukan secara kolaboratif antara guru Agama dengan guru kelas, yang membantu pelaksanaan observasi dan refleksi selama penelitian berlangsung, sehingga kegiatan penelitian ini dapat terkontrol untuk menjaga validitas hasil penelitian.

\section{Penjelasan Per Siklus}

Penelitian Tindakan Kelas dengan alur atau tahapan (perencanaan, pelaksanaan tindakan, observasi dan refleksi) disajikan dalam tiga siklus sebagai berikut:

Tabel 1 
Siklus I (Pertama)

\begin{tabular}{|c|c|c|c|c|}
\hline NO & PERENCANAAN & PELAKSANAAN & OBSERVASI & REFLEKSI \\
\hline 1 & $\begin{array}{l}\text { Menyusun Rencana } \\
\text { Pelaksanaan } \\
\text { Pembelajaran } \\
\text { dengan metode } \\
\text { smart game dan } \\
\text { pembelajaran } \\
\text { kooperatif tipe make } \\
\text { a match materi } \\
\text { Menyiapkan hand } \\
\text { out pembelajaran } \\
\text { Menyiapkan } \\
\text { lembar kerja siswa } \\
\text { Menyiapkan } \\
\text { blanko observasi } \\
\text { Menyiapkan } \\
\text { blanko evaluasi (pre } \\
\text { test dan post test) } \\
\text { menyiapkan } \\
\text { (make a match) } \\
\text { blanko jurnal harian } \\
\text { siswa permainan } \\
\text { Menyiapkan media }\end{array}$ & 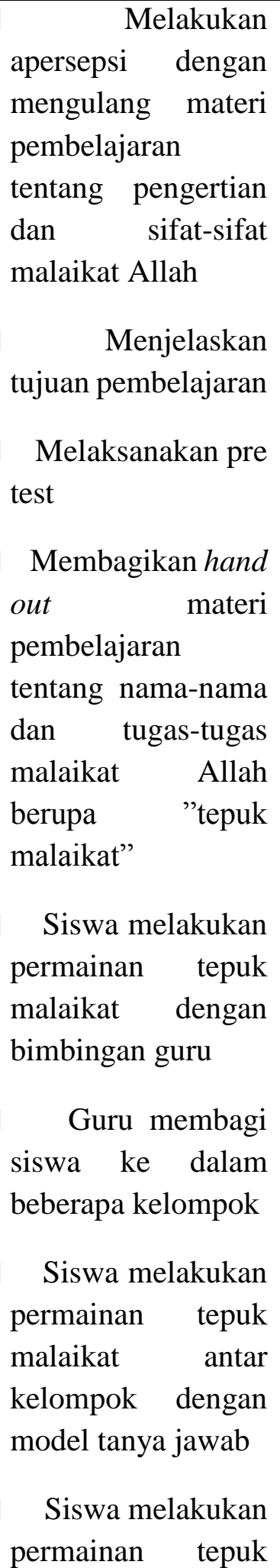 & $\begin{array}{l}\text { Mengamati } \\
\text { partisipasi siswa } \\
\text { dalam } \\
\text { pembelajaran } \\
\text { Mengamati guru } \\
\text { dalam aktivitas } \\
\text { pembelajaran } \\
\text { oleh teman } \\
\text { sejawat } \\
\text { Mengamati } \\
\text { pengelolaan kelas } \\
\text { Mengamati } \\
\text { respon siswa } \\
\text { terhadap } \\
\text { pembelajaran }\end{array}$ & $\begin{array}{l}\text { Mencatat hasil } \\
\text { observasi } \\
\text { Mengevaluasi } \\
\text { hasil observasi } \\
\text { Menganalisis } \\
\text { hasil } \\
\text { pembelajaran } \\
\text { Memperbaiki } \\
\text { kelemahan } \\
\text { untuk siklus } \\
\text { berikutnya }\end{array}$ \\
\hline
\end{tabular}




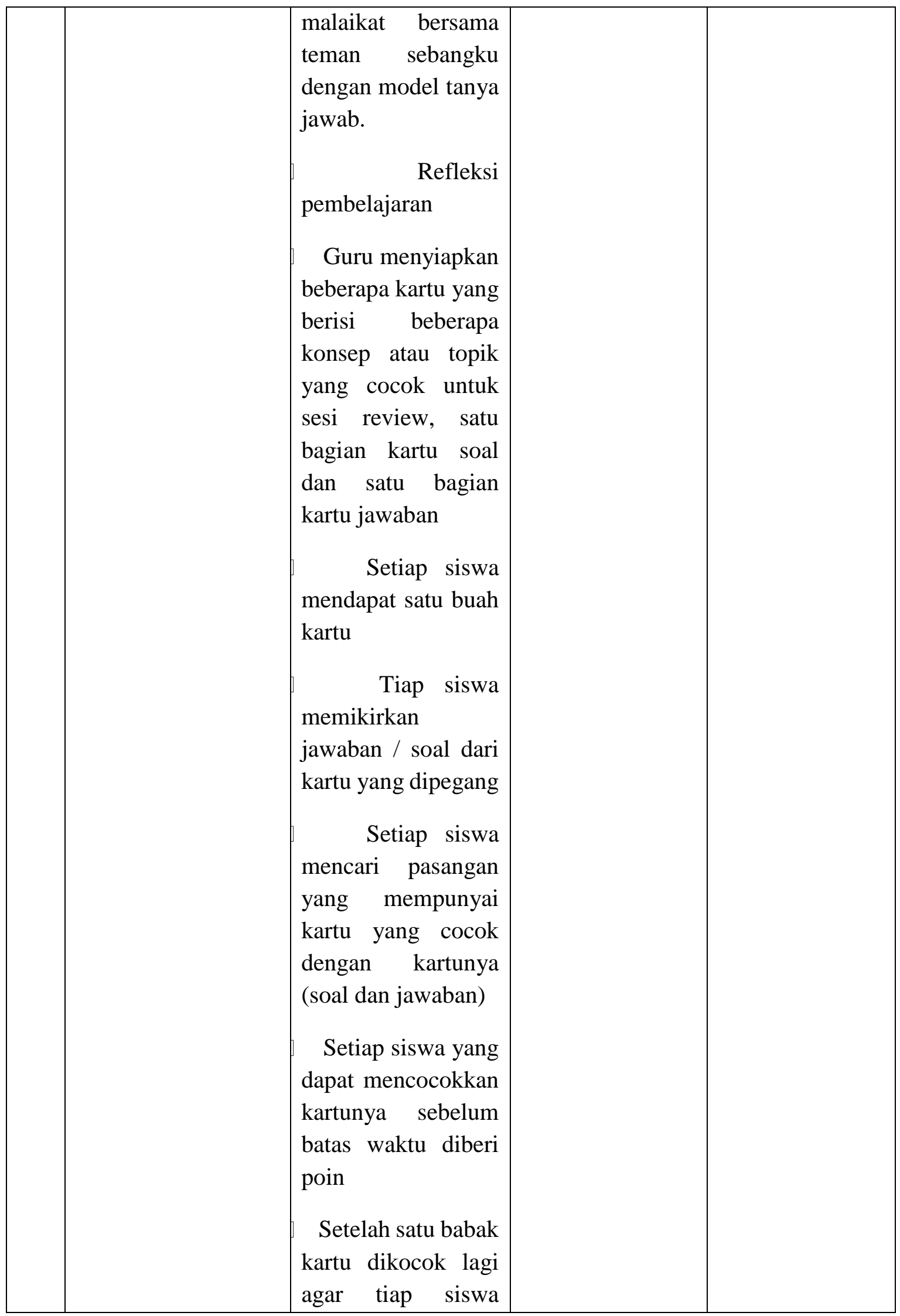




\begin{tabular}{|l|l|l|l|}
\hline & $\begin{array}{l}\text { mendapat kartu } \\
\text { yang berbeda dari } \\
\text { sebelumnya. } \\
\text { Demikian } \\
\text { seterusnya } \\
\text { Melakukan post } \\
\text { test }\end{array}$ & & \\
\hline
\end{tabular}

Beberapa kelemahan dan kesulitan yang ditemukan pada siklus I ini adalah: Dalam model pembelajaran make match, pada siklus ini hanya dilakukan 2 babak, sehingga siswa belum maksimal mempelajari nama-nama dan tugas-tugas malaikat Allah, salam model pembelajaran make match, beberapa siswa masih belum memahami aturan permainan sehingga ditemukan beberapa siswa yang mencari pasangan yang sama (soal-soal, jawaban-jawaban). Tetapi dengan penjelasan secara ringkas, kesulitan ini dapat segera dipahami siswa. Dalam model pembelajaran make match, beberapa siswa enggan bila mendapatkan pasangan kartu yang berbeda jenis kelamin. Dalam model pembelajaran make match, guru kurang mempersiapkan kartu permainan, sehingga ditemukan siswa yang tidak mendapatkan pasangan jawaban / soal.

Dari beberapa kesulitan di atas, pada tahap refleksi, guru bersama teman sejawat berkesimpulan untuk melakukan perbaikan, antara lain pelaksanaan pembelajaran make a match paling tidak dilakukan 5 babak sehingga siswa belajar secara maksimal. Perbedaan jenis kelamin juga perlu diperhatikan agar partisipasi siswa dalam pembelajaran selanjutnya lebih maksimal. Persiapan kartu soal dan jawaban juga perlu diperhatikan agar tidak ada siswa yang tidak mendapatkan pasangan (soal dan jawaban).

Tabel 2

Siklus II (Kedua)

\begin{tabular}{|c|c|c|c|c|}
\hline NO & PERENCANAAN & PELAKSANAAN & OBSERVASI & REFLEKSI \\
\hline 2 & $\begin{array}{l}\text { Menyusun } \\
\text { Rencana } \\
\text { Pelaksanaan } \\
\text { Pembelajaran } \\
\text { berdasarkan hasil } \\
\text { refleksi pada siklus } \\
\text { I } \\
\text { Menyiapkan soal } \\
\text { / masalah }\end{array}$ & $\begin{array}{l}\text { Melakukan } \\
\text { apersepsi dengan } \\
\text { mengulang materi } \\
\text { pembelajaran } \\
\text { Menjelaskan } \\
\text { tujuan } \\
\text { pembelajaran } \\
\text { Siswa melakukan } \\
\text { permainan tepuk }\end{array}$ & $\begin{array}{l}\text { Mengamati } \\
\text { partisipasi dan } \\
\text { kreativitas } \\
\text { siswa dalam } \\
\text { pembelajaran } \\
\text { Mengamati } \\
\text { guru dalam } \\
\text { aktivitas } \\
\text { pembelajaran }\end{array}$ & $\begin{array}{l}\text { Mencatat hasil } \\
\text { observasi } \\
\text { Mengevaluasi } \\
\text { hasil observasi } \\
\text { Menganalisis } \\
\text { hasil } \\
\text { pembelajaran }\end{array}$ \\
\hline
\end{tabular}




\begin{tabular}{|c|c|c|c|}
\hline 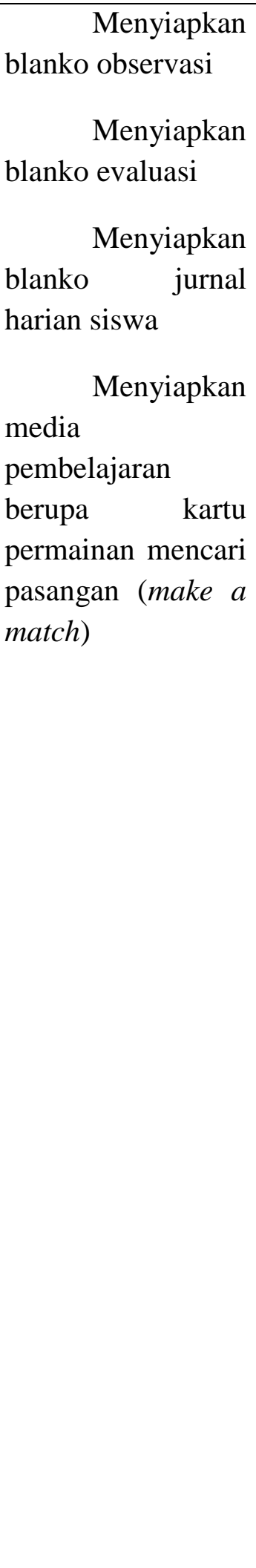 & 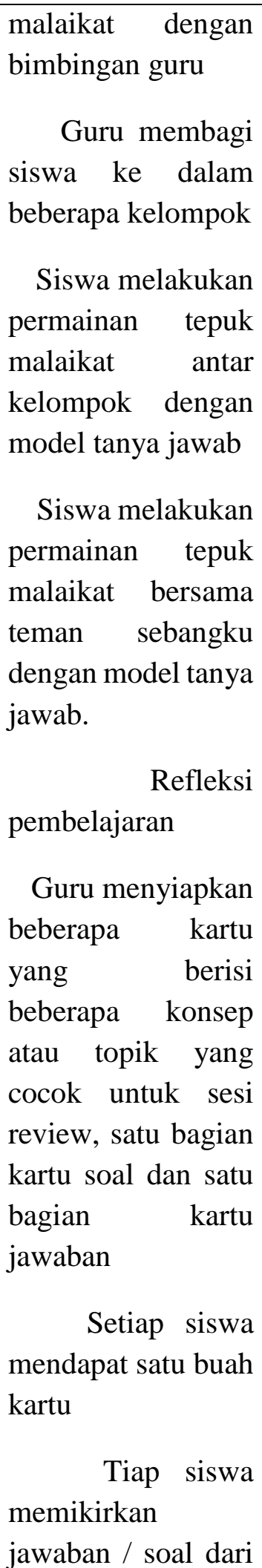 & $\begin{array}{l}\text { oleh teman } \\
\text { sejawat } \\
\text { Mengamati } \\
\text { pengelolaan } \\
\text { kelas } \\
\text { Mengamati } \\
\text { respon siswa } \\
\text { terhadap } \\
\text { pembelajaran }\end{array}$ & $\begin{array}{l}\text { Memperbaiki } \\
\text { kelemahan } \\
\text { untuk siklus } \\
\text { berikutnya }\end{array}$ \\
\hline
\end{tabular}




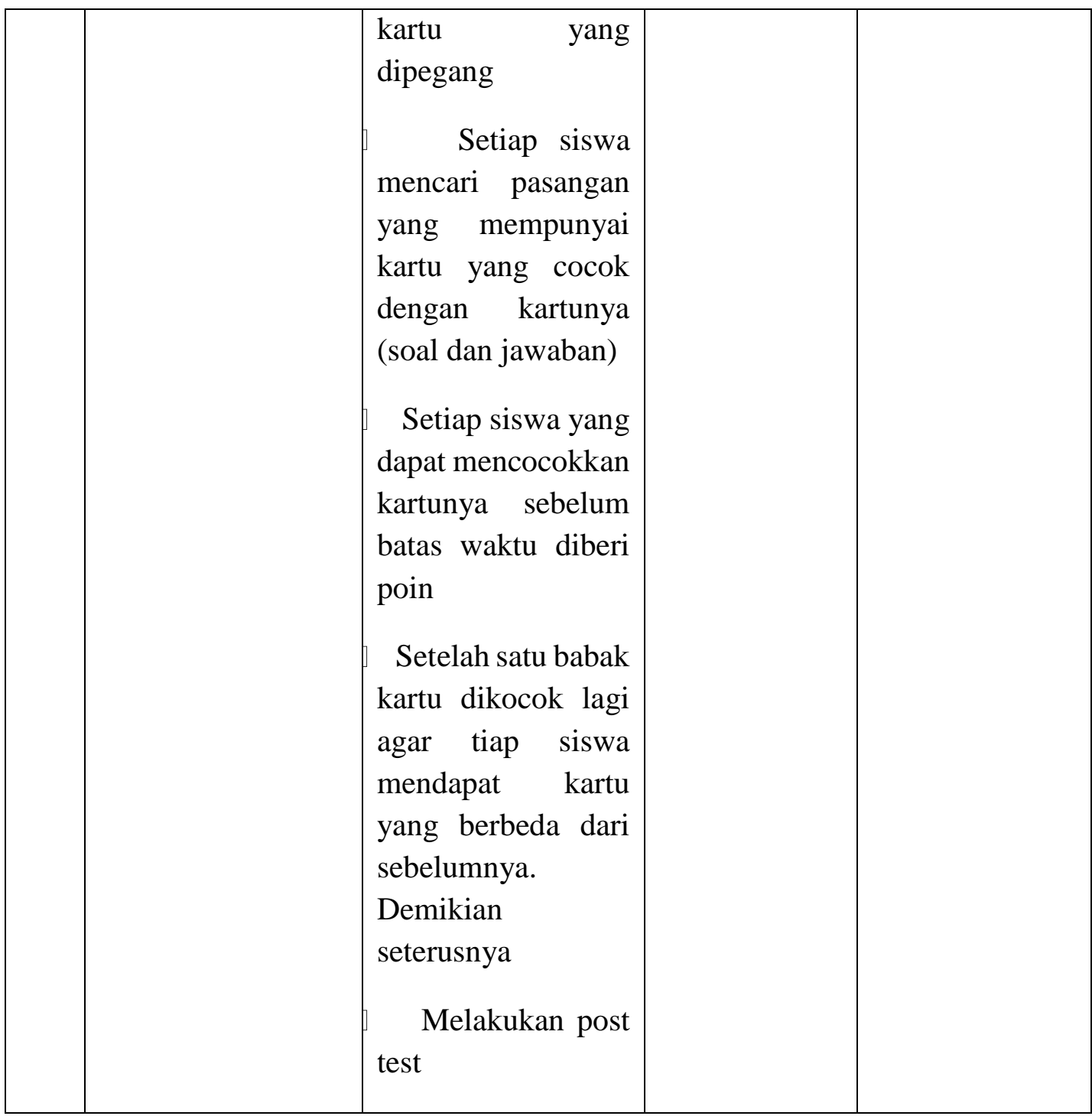

Beberapa kelemahan dan kesulitan yang ditemukan pada siklus II, yaitu;

1. Pembelajaran make a match membutuhkan kemampuan hafalan nama-nama dan tugas-tugas malaikat Allah. Setelah melakukan pembelajaran dengan metode smart game dengan permainan tepuk malaikat, ditemukan beberapa siswa yang belum hafal secara sempurna sehingga berpengaruh pada permainan make a match

2. Ditemukan beberapa kesalahan dalam pembelajaran make a match terutama dalam mencari pasangan antara tugas malaikat Izrail dan Israfil, malaikar Raqib dan Atid, dan malaikat Ridwan dan Malik. Hal ini sebagai akibat dari hafalan siswa yang belum sempurna.

Dalam siklus ini, sudah tidak ditemukan lagi adanya keengganan siswa yang mendapatkan pasangan dengan perbedaan jenis kelamin. Guru juga sudah 
mempersiapkan kartu permainan make a macth dengan lebih sempurna sehingga memungkinkan siswa mendapatkan pasangan (nama dan tugas malaikat). Hanya saja ditemukan jumlah siswa yang ganjil sehingga dimungkinkan adanya siswa yang tidak mendapatkan pasangan. Dalam sisklus ini juga permainan make a match dilakukan dalam 5 babak sehingga siswa belajar lebih maksimal, walaupun ada beberapa siswa yang mendapatkan kartu yang sama dalam babak berikutnya.

Dari beberapa kesulitan di atas, pada tahap refleksi, guru bersama teman sejawat berkesimpulan untuk melakukan perbaikan yaitu guru melakukan pengecekan hafalan nama-nama dan tugas-tugas malaikat Allah dengan permainan tepuk malaikat.

Tabel 3

Siklus III (Ketiga)

\begin{tabular}{|c|c|c|c|c|}
\hline NO & PERENCANAAN & PELAKSANAAN & OBSERVASI & REFLEKSI \\
\hline 3 & $\begin{array}{l}\text { Menyusun } \\
\text { Rencana } \\
\text { Pelaksanaan } \\
\text { Pembelajaran } \\
\text { berdasarkan hasil } \\
\text { refleksi pada siklus } \\
\text { I } \\
\text { Menyiapkan soal } \\
\text { / masalah } \\
\text { Menyiapkan } \\
\text { blanko observasi } \\
\text { Menyiapkan } \\
\text { blanko evaluasi } \\
\text { Menyiapkan } \\
\text { blanko jurnal } \\
\text { harian siswa } \\
\text { Menyiapkan } \\
\text { media kembelajaran } \\
\text { berupa artu } \\
\text { permainan mencari }\end{array}$ & $\begin{array}{l}\text { Melakukan } \\
\text { apersepsi dengan } \\
\text { mengulang materi } \\
\text { pembelajaran } \\
\text { Menjelaskan } \\
\text { tujuan } \\
\text { pembelajaran } \\
\text { Siswa melakukan } \\
\text { permainan tepuk } \\
\text { malaikat dengan } \\
\text { bimbingan guru } \\
\text { Guru membagi } \\
\text { siswa ke dalam } \\
\text { beberapa kelompok } \\
\text { Siswa melakukan } \\
\text { permainan tepuk } \\
\text { malaikat antar } \\
\text { kelompok dengan } \\
\text { model tanya jawab } \\
\text { Siswa melakukan } \\
\text { permainan tepuk } \\
\text { malaikat bersama }\end{array}$ & $\begin{array}{l}\text { Mengamati } \\
\text { partisipasi dan } \\
\text { kreativitas } \\
\text { siswa dalam } \\
\text { pembelajaran } \\
\text { Mengamati } \\
\text { guru dalam } \\
\text { aktivitas } \\
\text { pembelajaran } \\
\text { oleh teman } \\
\text { sejawat } \\
\text { Mengamati } \\
\text { pengelolaan } \\
\text { kelas } \\
\text { Mengamati } \\
\text { respon siswa } \\
\text { terhadap } \\
\text { pembelajaran }\end{array}$ & $\begin{array}{l}\text { Mencatat hasil } \\
\text { observasi } \\
\text { Mengevaluasi } \\
\text { hasil observasi } \\
\text { Menganalisis } \\
\text { hasil } \\
\text { pembelajaran }\end{array}$ \\
\hline
\end{tabular}




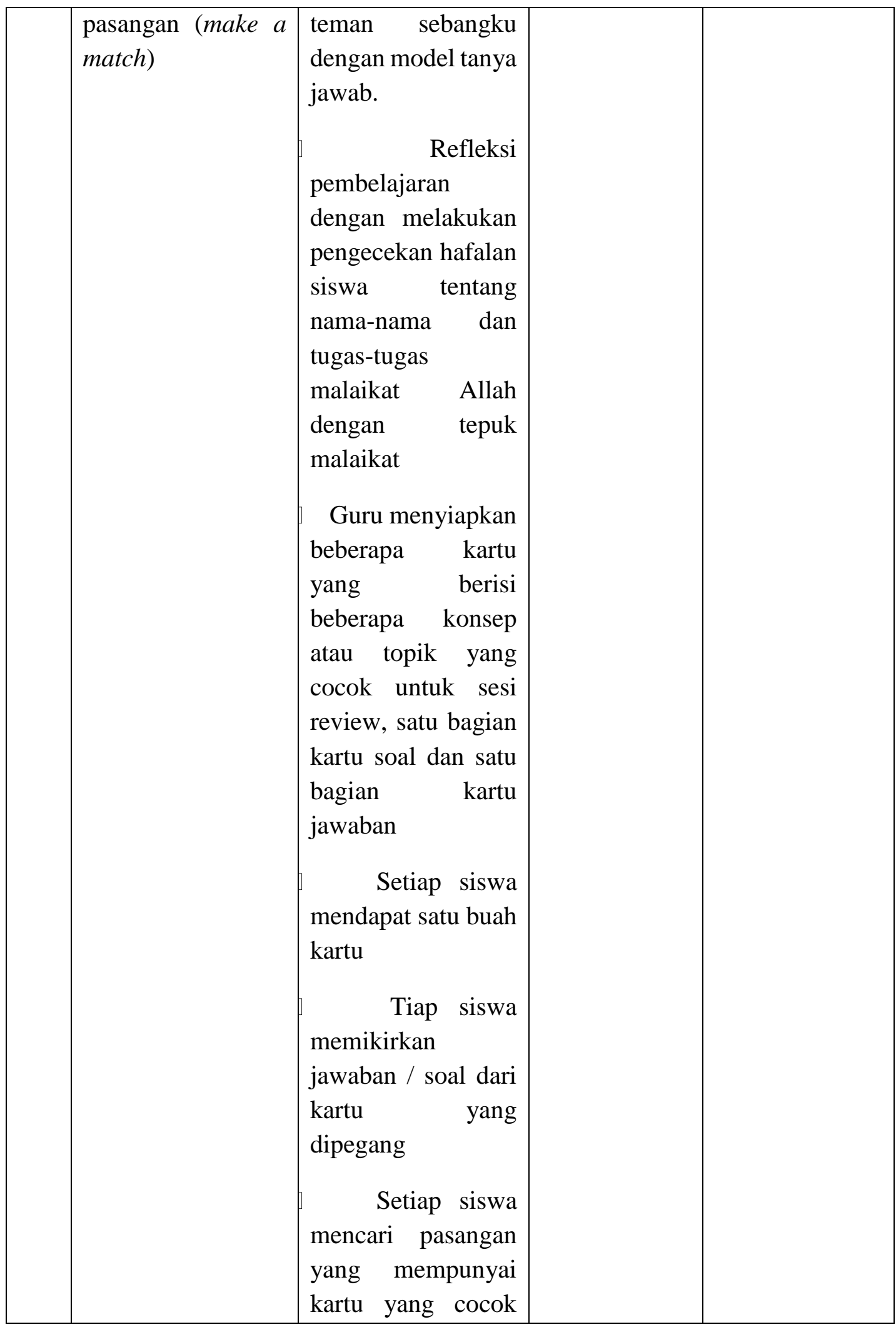




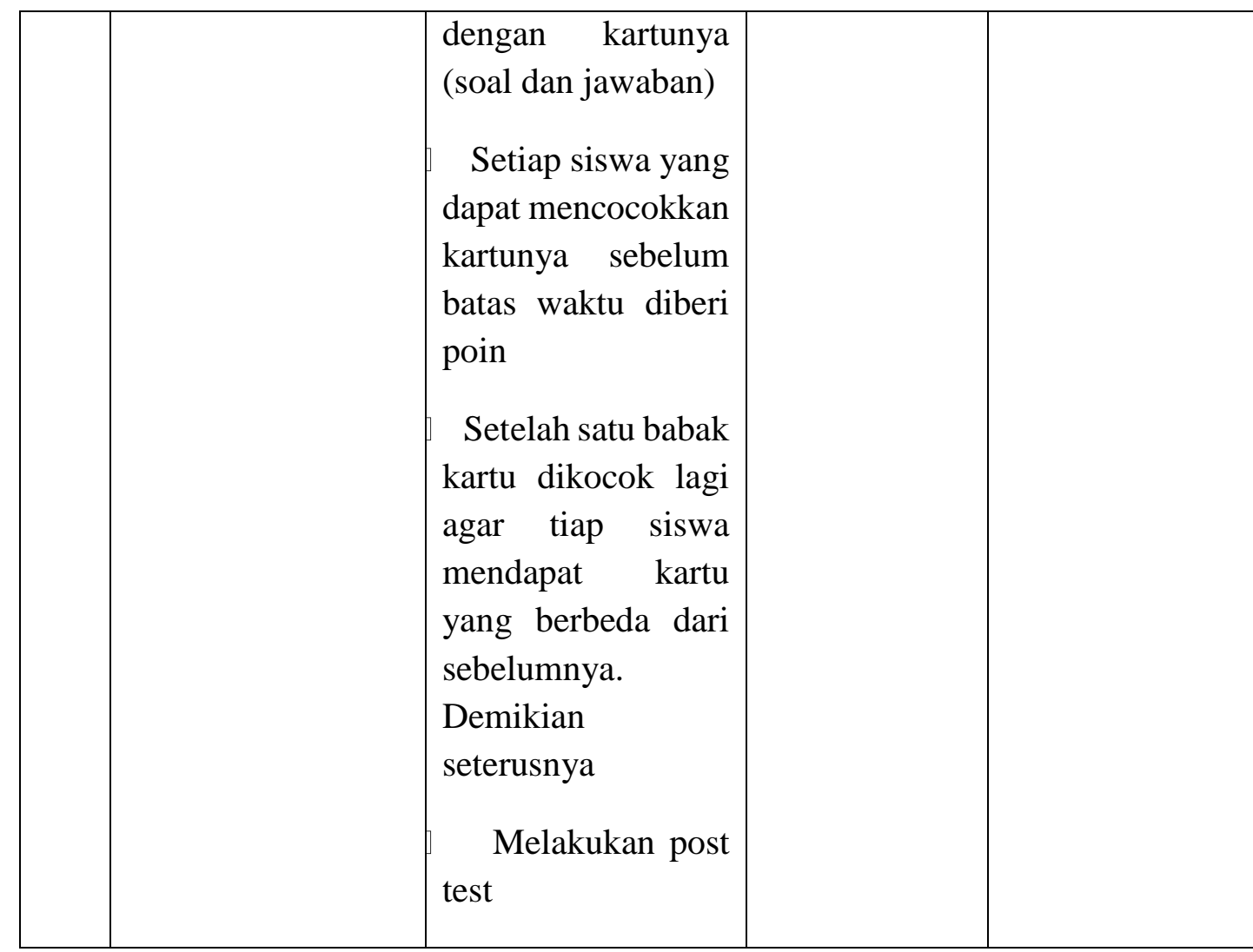

Tidak ada kendala berarti dalam siklus III. Hanya beberapa siswa masih ditemukan kesalahan dalam pembelajaran make a match terutama dalam mencari pasangan antara tugas malaikat Izrail dan Israfil, malaikar Raqib dan Atid, dan malaikat Ridwan dan Malik. Tetapi dapat diatasi dengan bimbingan guru dalam pembelajaran make a match.

Dalam melakukan tindakan kelas selama tiga siklus, ternyata ada 2 (dua) siswa yang tidak mengikuti sama sekali, yaitu siswa S21 dan S39 dan 11 siswa yang tidak mengikuti keseluruhan siklus, yaitu siswa S5, S8, S10, S11, S16, S17, S18, S20, S22, S23, dan S42. Oleh karena itu peneliti menetapkan subyek penelitian ini menjadi 29 siswa, 14 siswa laki-laki dan 15 siswa perempuan

\section{Deskripsi Data dan Analisis Data}

Dari hasil pre tes dan penilaian tes tulis dalam 3 siklus, diperoleh data sebagai berikut:

Tabel 4

Daftar Nilai Pre Tes, Siklus I, II dan III

\begin{tabular}{|c|c|c|c|c|c|c|c|c|c|}
\hline \multirow{2}{*}{ NO } & \multirow{2}{*}{ NAMA } & \multicolumn{2}{c|}{ PRE TES } & \multicolumn{2}{c|}{ SIKLUS I } & \multicolumn{2}{c|}{ SIKLUS II } & \multicolumn{2}{c|}{ SIKLUS III } \\
\cline { 3 - 10 } & SISWA & SKOR & NILAI & SKOR & NILAI & SKOR & NILAI & SKOR & NILAI \\
\hline 1. & S 1 & 2 & 22 & 4 & 44 & 5 & 56 & 9 & 100 \\
\hline
\end{tabular}




\begin{tabular}{|c|c|c|c|c|c|c|c|c|c|}
\hline 2. & S2 & 4 & 44 & 9 & 100 & 9 & 100 & 9 & 100 \\
\hline 3. & S3 & 4 & 44 & 6 & 67 & 9 & 100 & 9 & 100 \\
\hline 4. & S4 & 4 & 44 & 3 & 33 & 6 & 67 & 2 & 22 \\
\hline 5. & S6 & 4 & 44 & 4 & 44 & 2 & 22 & 7 & 78 \\
\hline 6. & S7 & 3 & 33 & 7 & 78 & 5 & 56 & 9 & 100 \\
\hline 7. & S9 & 9 & 100 & 9 & 100 & 9 & 100 & 9 & 100 \\
\hline 8. & $\mathrm{~S} 12$ & 1 & 11 & 9 & 100 & 9 & 100 & 9 & 100 \\
\hline 9. & S13 & 2 & 22 & 7 & 78 & 9 & 100 & 9 & 100 \\
\hline 10. & S14 & 9 & 100 & 9 & 100 & 5 & 56 & 9 & 100 \\
\hline 11. & $\mathrm{~S} 15$ & 1 & 11 & 5 & 56 & 5 & 56 & 7 & 78 \\
\hline 12. & $\mathrm{~S} 19$ & 3 & 33 & 9 & 100 & 9 & 100 & 7 & 78 \\
\hline 13. & S24 & 2 & 22 & 7 & 78 & 5 & 56 & 9 & 100 \\
\hline 14. & S25 & 5 & 56 & 4 & 44 & 5 & 56 & 9 & 100 \\
\hline 15. & S26 & 2 & 22 & 5 & 56 & 7 & 78 & 7 & 78 \\
\hline 16. & S27 & 2 & 22 & 5 & 56 & 9 & 100 & 9 & 100 \\
\hline 17. & $\mathrm{~S} 28$ & 3 & 33 & 4 & 44 & 5 & 56 & 9 & 100 \\
\hline 18. & S29 & 4 & 44 & 9 & 100 & 7 & 78 & 7 & 78 \\
\hline 19. & $\mathrm{~S} 30$ & 4 & 44 & 8 & 89 & 9 & 100 & 9 & 100 \\
\hline 20. & S31 & 2 & 22 & 9 & 100 & 9 & 100 & 9 & 100 \\
\hline 21. & S32 & 3 & 33 & 3 & 33 & 5 & 56 & 7 & 78 \\
\hline 22. & S33 & 2 & 22 & 9 & 100 & 7 & 78 & 7 & 78 \\
\hline 23. & S34 & 3 & 33 & 7 & 78 & 9 & 100 & 7 & 78 \\
\hline 24. & S35 & 3 & 33 & 4 & 44 & 8 & 89 & 7 & 78 \\
\hline 25. & S36 & 1 & 11 & 2 & 22 & 9 & 100 & 9 & 100 \\
\hline 26. & S37 & 1 & 11 & 7 & 78 & 5 & 56 & 9 & 100 \\
\hline 27. & S38 & 5 & 56 & 9 & 100 & 9 & 100 & 9 & 100 \\
\hline 28. & $\mathrm{~S} 40$ & 1 & 11 & 9 & 100 & 9 & 100 & 9 & 100 \\
\hline 29. & $\mathrm{~S} 41$ & 3 & 33 & 4 & 44 & 5 & 56 & 7 & 78 \\
\hline \multicolumn{2}{|c|}{ JUMLAH } & & 1016 & & 2066 & & 2272 & & 2602 \\
\hline \multicolumn{2}{|c|}{$R A T A-R A T A$} & & 35.03 & & 71.24 & & 78.34 & & 89.72 \\
\hline
\end{tabular}

Perbandingan dan peningkatan keberhasilan yang diperoleh pada pre tes, siklus I, II dan III sebagai berikut:

Tabel 5

Rekapitulasi Persentase dan Nilai Pre tes, Siklus I, II dan III

\begin{tabular}{|c|c|c|c|c|c|c|c|c|c|c|c|c|c|}
\hline \multirow[b]{2}{*}{$\begin{array}{l}\mathrm{N} \\
\mathrm{O}\end{array}$} & \multirow[b]{2}{*}{ KATEGORI } & \multicolumn{3}{|c|}{ PRE TES } & \multicolumn{3}{|c|}{ SIKLUS I } & \multicolumn{3}{|c|}{ SIKLUS II } & \multicolumn{3}{|c|}{ SIKLUS III } \\
\hline & & $\begin{array}{c}\text { Jml } \\
\text { sis } \\
\text { wa }\end{array}$ & $\%$ & $\begin{array}{l}\text { Rat } \\
\text { a- } \\
\text { rata }\end{array}$ & $\begin{array}{c}\text { Jml } \\
\text { sis } \\
\text { wa }\end{array}$ & $\%$ & $\begin{array}{l}\text { Rat } \\
\text { a- } \\
\text { rata }\end{array}$ & $\begin{array}{c}\text { Jml } \\
\text { sis } \\
\text { wa }\end{array}$ & $\%$ & $\begin{array}{l}\text { Rat } \\
\text { a- } \\
\text { rata }\end{array}$ & $\begin{array}{c}\text { Jml } \\
\text { sis } \\
\text { wa }\end{array}$ & $\%$ & $\begin{array}{l}\text { Rat } \\
\text { a- } \\
\text { rata }\end{array}$ \\
\hline
\end{tabular}


Siti Parihah

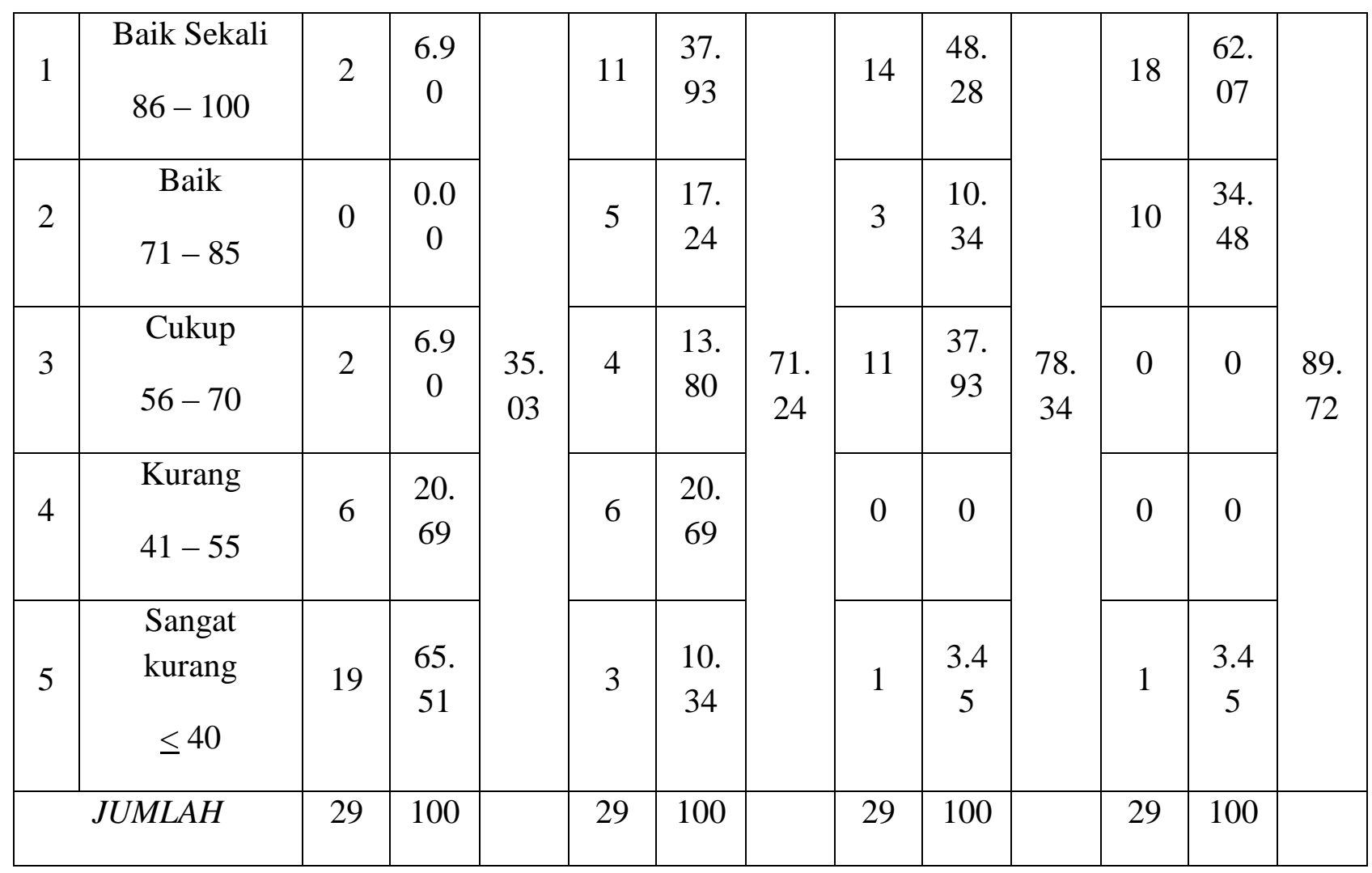

Dari data tersebut, diketahui bahwa nilai rata-rata pada saat dilakukan pre test 35.03. Artinya pemahaman siswa terhadap materi pembelajaran "nama-nama da tugastugas malaikat Allah" masih dalam kategori sangat kurang. Sebagian besar siswa $(65.51 \%)$ mendapat nilai berkategori sangat kurang, yakni 19 orang, kategori kurang 6 orang (20.69\%), kategori cukup 2 orang $(6.90 \%)$, kategori baik 0 orang $(0.00 \%)$ dan baik sekali 2 orang $(6.90 \%)$.

Setelah dilakukan tindakan pada siklus I, nilai rata-rata 71.24. Pada siklus I ini sudah dapat tergambarkan peningkatan pemahaman siswa terhadap materi pembelajaran. Sebagian besar siswa (37.93\%) mendapat nilai berkategori baik sekali, yakni 11 orang, kategori baik 5 orang (17.24\%), kategori cukup 4 orang (13.80\%), kategori kurang 6 orang $(20.69 \%)$ dan kategori sangat kurang 3 orang (10.34\%). Dari data di atas dapat disimpulkan bahwa nilai rata-rata kelas berkategori baik dan $68.98 \%$ siswa mendapat nilai berkategori cukup ke atas.

Setelah dilakukan perbaikan, nilai rata-rata kelas pada siklus II 78.34. Pada siklus ini, tingkat pemahaman siswa terhadap materi pembelajaran semakin meningkat. Sebagian besar siswa mendapat nilai berkategori baik sekali, yakni 14 orang (48.28\%). Siswa berkategori baik 3 orang (10.34\%), berkategori cukup 11 orang (37.93\%) dan berkategori kurang sekali hanya 1 orang $(3.45 \%)$. Dari data di atas, dapat disimpulkan 
bahwa nilai rata-rata kelas berkategori baik dan $96.55 \%$ siswa mendapat nilai berkategori cukup ke atas.

Tindakan pada siklus III dilakukan dan hasilnya sangat mengagumkan. Tingkat pemahaman siswa terhadap materi sangat baik. Nilai rata-rata kelas 89.72. Sebagian besar siswa mendapat nilai berkategori baik sekali (18 orang, 62.07\%), kategori baik 10 orang $(34.48 \%)$, sedangkan sisanya berkategori sangat kurang hanya 1 orang $(3.45 \%)$. Dari data di atas dapat disimpulkan bahwa nilai rata-rata kelas berkategori baik sekali dan $96.55 \%$ siswa mendapat nilai berkategori cukup ke atas. $3.45 \%$ (1 orang) siswa yang yang mendapat nilai sangat kurang merupakan siswa yang belum lancar membaca dan menulis. Dan ini menunjukkan bahwa kemampuan membaca siswa sangat berpengaruh terhadap pemahaman siswa terhadap materi pembelajaran.

Kesan siswa terhadap pembelajaran dapat dikelompokkan menjadi kesan positif dan negatif. Kesan positif yaitu respon baik siswa terhadap pembelajaran. Sedangkan kesan negatif yaitu ketidaktertarikan siswa terhadap pembelajaran. Hasil jurnal harian siswa tersebut dapat diperoleh dari data sebagai berikut:

Tabel 6

Kesan Siswa terhadap Pembelajaran dengan Metode Smart Game dan Pembelajaran Kooperatif Tipe Make a Match

\begin{tabular}{|c|c|c|c|c|c|c|}
\hline \multirow{2}{*}{ Kategori } & \multicolumn{6}{|c|}{ Kesan siswa } \\
\cline { 2 - 7 } & SIKLUS I & $\%$ & $\begin{array}{c}\text { SIKLUS } \\
\text { II }\end{array}$ & $\%$ & $\begin{array}{c}\text { SIKLUS } \\
\text { III }\end{array}$ & $\%$ \\
\hline POSITIF & 29 & 100 & 29 & 100 & 29 & 100 \\
\hline BIASA & 0 & 0 & 0 & 0 & 0 & 0 \\
\hline NEGATIF & 0 & 0 & 0 & 0 & 0 & 0 \\
\hline
\end{tabular}

Dari data di atas, dapat diketahui bahwa pembelajaran dengan menggunakan metode smart game dan pembelajaran kooperatif tipe make a match mendapatkan respon yang positif dari siswa. Rata-rata respon positif siswa dari ketiga siklus adalah $100 \%$.

Partisipasi siswa dalam pembelajaran dapat dilihat dari perolehan poin pada pembelajaran kooperatif tipe make a match. Poin yang dikemukakan di sini hanya poin pada siklus II dan III yang dilakukan 5 babak. Sedangkan pada pembelajaran make a match siklus I hanya dilakukan 2 babak sehingga tidak dapat diperbandingkan.

Tabel 7

Poin Siswa pada Pembelajaran Kooperatif tipe Make a Match 
Siti Parihah

\begin{tabular}{|c|c|c|c|c|c|}
\hline \multirow{2}{*}{ NO } & \multirow{2}{*}{$\begin{array}{l}\text { NAMA } \\
\text { SISWA }\end{array}$} & \multicolumn{2}{|c|}{ SIKLUS II } & \multicolumn{2}{|c|}{ SIKLUS III } \\
\hline & & POIN & $\%$ & POIN & $\%$ \\
\hline 1. & S1 & 4 & 80 & 5 & 100 \\
\hline 2. & S2 & 5 & 100 & 5 & 100 \\
\hline 3. & S3 & 4 & 80 & 5 & 100 \\
\hline 4. & S4 & 5 & 100 & 4 & 80 \\
\hline 5. & S6 & 4 & 80 & 5 & 100 \\
\hline 6. & S7 & 5 & 100 & 5 & 100 \\
\hline 7. & S9 & 5 & 100 & 5 & 100 \\
\hline 8. & S12 & 4 & 80 & 5 & 100 \\
\hline 9. & S13 & 4 & 80 & 5 & 100 \\
\hline 10. & S14 & 4 & 80 & 5 & 100 \\
\hline 11. & S15 & 4 & 80 & 5 & 100 \\
\hline 12. & S19 & 5 & 100 & 5 & 100 \\
\hline 13. & S24 & 4 & 80 & 4 & 80 \\
\hline 14. & $\mathrm{~S} 25$ & 5 & 100 & 5 & 100 \\
\hline 15. & S26 & 4 & 80 & 4 & 80 \\
\hline 16. & S27 & 5 & 100 & 5 & 100 \\
\hline 17. & S28 & 4 & 80 & 5 & 100 \\
\hline 18. & S29 & 4 & 80 & 5 & 100 \\
\hline 19. & S30 & 5 & 100 & 4 & 80 \\
\hline 20. & S31 & 5 & 100 & 5 & 100 \\
\hline 21. & S32 & 5 & 100 & 4 & 80 \\
\hline 22. & S33 & 5 & 100 & 5 & 100 \\
\hline 23. & S34 & 5 & 100 & 4 & 80 \\
\hline 24. & S35 & 5 & 100 & 5 & 100 \\
\hline 25. & S36 & 4 & 80 & 5 & 100 \\
\hline 26. & S37 & 5 & 100 & 5 & 100 \\
\hline 27. & S38 & 5 & 100 & 5 & 100 \\
\hline 28. & S40 & 4 & 80 & 5 & 100 \\
\hline 29. & S41 & 5 & 100 & 5 & 100 \\
\hline \multicolumn{2}{|c|}{ JUMLAH } & & 2640 & & 2780 \\
\hline \multicolumn{2}{|c|}{$R A T A-R A T A$} & & 91.03 & & 95.86 \\
\hline
\end{tabular}

Dari poin rata-rata siswa pada pembelajaran kooperatif tipe make a match di atas, dapat disimpulkan bahwa partisipasi siswa dalam pembelajaran sangat tinggi. Pada siklus II, rata-rata poin 91.03 naik menjadi 95.86 pada siklus III.

Adapun hasil pengamatan observer terhadap aktifitas guru dalam proses pembelajaran berlangsung pada siklus I, II dan III pada tabel berikut:

Tabel 8 
Format Observasi

Aktivitas Guru Dalam Proses Pembelajaran

\begin{tabular}{|c|c|c|c|c|c|c|c|c|c|c|c|c|c|c|c|c|}
\hline \multirow{2}{*}{ NO } & \multirow{2}{*}{$\begin{array}{c}\text { AKTIVITAS } \\
\text { YANG } \\
\text { DIAMATI }\end{array}$} & \multicolumn{5}{|c|}{ SIKLUS I } & \multicolumn{5}{|c|}{ SIKLUS II } & \multicolumn{5}{|c|}{ SIKLUS III } \\
\hline & & 1 & 2 & 3 & 4 & 5 & 1 & 2 & 3 & 4 & 5 & 1 & 2 & 3 & 4 & 5 \\
\hline 1 & $\begin{array}{l}\text { Melakukan } \\
\text { Apersepsi }\end{array}$ & & & & & $\mathrm{V}$ & & & & & V & & & & & V \\
\hline 2 & $\begin{array}{l}\text { Menyampaikan } \\
\text { tujuan } \\
\text { pembelajaran }\end{array}$ & & & V & & & & & & $\mathrm{V}$ & & & & & $\mathrm{V}$ & \\
\hline 3 & $\begin{array}{l}\text { Melakukan Pre } \\
\text { tes }\end{array}$ & & & & V & & & & & $\mathrm{V}$ & & & & & $\mathrm{V}$ & \\
\hline 4 & $\begin{array}{l}\text { Memilih materi } \\
\text { pembelajaran }\end{array}$ & & & & & $\mathrm{V}$ & & & & & V & & & & & V \\
\hline 5 & $\begin{array}{l}\text { Memilih dan } \\
\text { menggunakan } \\
\text { metode } \\
\text { pembelajaran }\end{array}$ & & & & V & & & & & $\mathrm{V}$ & & & & & & V \\
\hline 6 & $\begin{array}{l}\text { Memilih dan } \\
\text { menggunakan } \\
\text { media } \\
\text { pembelajaran }\end{array}$ & & & & V & & & & & & V & & & & & V \\
\hline 7 & $\begin{array}{l}\text { Pengorganisasian } \\
\text { siswa }\end{array}$ & & V & & & & & & & $\mathrm{V}$ & & & & & & V \\
\hline 8 & $\begin{array}{l}\text { Menarik } \\
\text { kesimpulan }\end{array}$ & & & V & & & & & & $\mathrm{V}$ & & & & & $\mathrm{V}$ & \\
\hline 9 & $\begin{array}{l}\text { Melakukan } \\
\text { penilaian proses }\end{array}$ & & & & $\mathrm{V}$ & & & & & $\mathrm{V}$ & & & & & & V \\
\hline 10 & $\begin{array}{l}\text { Melakukan } \\
\text { penilaian akhir }\end{array}$ & & & & & V & & & & & V & & & & & V \\
\hline & JUMLAH & & 1 & 6 & 16 & 15 & & & & 24 & 20 & & & & 12 & 35 \\
\hline
\end{tabular}




\begin{tabular}{|c|c|c|c|}
\hline & $\begin{array}{c}38 / 50 \times 100 \%= \\
76 \%\end{array}$ & $84 / 50 \times 100 \%=$ & $47 / 50 \times 100 \%=$ \\
& $88 \%$ & $94 \%$ \\
\hline
\end{tabular}

Dari data di atas, berdasarkan pengamatan teman sejawat selaku observer menunjukkan bahwa pada siklus I pengorganisasian siswa perlu diperbaiki dan disempurnakan. Pada siklus selanjutnya tampak peningkatan secara signifikan yaitu berada pada kategori 5 .

\section{HASIL PENELITIAN DAN PEMBAHASAN}

\section{A. Pembahasan Hasil Penelitian}

1. Keberhasilan secara Kuantitatif

Berdasarkan data yang diperoleh dari hasil penilaian tertulis menunjukkan bahwa setelah dilakukan tindakan pada Siklus I, II, dan III dengan menggunakan metode smart game dan pembelajaran kooperatif tipe make a match dapat meningkatkan kemampuan menyebutkan nama-nama dan tugas-tugas Malaikat Allah SWT..

Jika dibandingkan dengan hasil pre test, terjadi peningkatan sangat signifikan kemampuan siswa menyebutkan nama-nama dan tugas-tugas malaikat Allah (lihat grafik 1. persentase perolehan nilai dan grafik 2. peningkatan nilai rata-rata siswa).

2. Keberhasilan secara Kualitatif

Berdasarkan hasil jurnal harian siswa, diperoleh rata-rata respon positif siswa terhadap pembelajaran dengan menggunakan metode smart game dan pembelajaran kooperatif tipe make a match $100 \%$. Dan poin rata-rata siswa pada pembelajaran kooperatif tipe make a match di atas, dapat disimpulkan bahwa partisipasi siswa dalam pembelajaran sangat tinggi. Pada siklus II, rata-rata poin 91.03 naik menjadi 95.86 pada siklus III.

Bila dikonversikan ke dalam kategori keberhasilan yang peneliti tetapkan sebagai berikut:

$$
\begin{array}{lll}
\geq 80 \% & = & \text { sangat baik } \\
60-79.9 \% & = & \text { baik } \\
40-59.9 \% & = & \text { cukup } \\
20-39.9 \% & = & \text { kurang } \\
\leq \quad 20 \% & = & \text { sangat kurang }
\end{array}
$$

Maka diperoleh kesimpulan bahwa keberhasilan pembelajaran dengan menggunakan metode smart game dan pembelajaran kooperatif tipe make a match dapat dikategorikan sangat baik.

\section{SIMPULAN}

Berdasarkan hasil penelitian tindakan kelas, maka penulis menyimpulkan bahwa penggunaan metode smart game dan pembelajaran kooperatif tipe make a match dapat 
meningkatkan kemampuan menyebutkan nama-nama dan tugas-tugas malaikat Allah SWT. Hal ini dapat dilihat dari peningkatan perolehan nilai dari pre tes dampai siklus III secara signifikan. Respon siswa terhadap pembelajaran dengan menggunakan metode smart game dan pembelajaran kooperatif tipe make a match dapat dikategorikan sangat baik.

\section{SARAN}

Berdasarkan uraian yang telah dikemukakan, maka penulis menyarankan hal-hal berikut:

Pertama, Bagi guru, untuk meningkatkan kompetensi dan ketuntasan belajar siswa dalam pembelajaran PAI, agar dilakukan dengan pembelajaran aktif (active learning), menyenangkan (joyfull learning) dan bekerja sama dengan orang lain (cooperative learning) dan penggunaan metode smart game dan pembelajaran kooperatif tipe make a match dapat dijadikan sebagai alternatif.

Kedua, Bagi peneliti selanjutnya, mengingat manfaat yang diperoleh dari penelitian ini, maka diharapkan menjadi pertimbangan bagi peneliti selanjutnya, agar ditindak lanjuti dengan materi dan sekolah yang berbeda juga jenjang pendidikan yang berbeda pula dengan melibatkan subyek yang lebih luas dan metode penelitian yang berbeda. 
Siti Parihah

\section{DAFTAR PUSTAKA}

Alim, M. (2011). Pendidikan Agama Islam. Bandung: PT Remaja Rosdakarya.

Andayani, A. M. (2004). Pendidikan Agama Islam Berbasis Kompetensi. Bandung: PT Remaja Rosdakarya.

Aziz, R. Penggunaan Model Pembelajaran Kooperatif dan Kompetitif dalam Mengembangkan Kreatifitas, dipublikasikan pada jurnal: MADRASAH, Jurnal Pendidikan dan Pembelajaran Dasar, Vol 1, No 1, Juli-Desember 2008.

Daradjat, Z. (2006). Ilmu Pendidikan Islam. Jakarta: Bumi Aksara.

Holil, A. Model Pembelajaran Kooperatif, www.anwarholil.blogspot.com, diakses pada tanggal 10 Maret 2017.

Majid, A. (2012). Belajar dan Pembelajaran PAI. Bandung: PT Remaja Rosdakarya.

Majid, A. (2012). Perencanaan Pembelajaran. Bandung: PT Remaja Rosdakarya.

Ramayulis. (2002). Ilmu Pendidikan Islam. Jakarta: Kalam Mulia.

Rijal. Model Pembelajaran Kooperatif Tipe Make a Match, http://www.rijal09.com/2016/12/model-pembelajaran-kooperatif-tipe-make-amatch.html, diakses pada tanggal 10 Maret 2017.

Santoso, A. (tanpa tahun). Kamus Lengkap Bahasa Indonesia. Surabaya: Pustaka Dua.

Slavin, Robert E, Cooperative Learning, Teori, Riset dan Praktik, Terj : Nurulita, Bandung: Nusa media, 2008, Cet. III

Tim Ipotes. Metode Pembelajaran Kooperatif, www.ipotes.wordpress.com, diakses pada tanggal 10 Maret 2017 